\title{
Efficacy of High Resolution Magnetic Resonance Imaging in Preoperative Local Staging of Rectal Cancer
}

\author{
Rektum Kanserinin Preoperatif Lokal Evrelemesinde Yüksek Rezolüsyonlu Manyetik \\ Rezonans Görüntülemenin Etkinliği
}

\author{
Aysun Uçar', Funda Obuz', Selman Sökmen², Cem Terzi², Özgül Sağol3, Sülen Sarıŏlu³, Mehmet Füzün² \\ IDokuz Eylül University, Department of Radiology, Izmir, Turkey \\ 2Dokuz Eylül University, Department of General Surgery, Izmir, Turkey \\ 3Dokuz Eylül University, Department of Pathology, Izmir, Turkey
}

\begin{abstract}
Objective: To assess the efficacy of high-resolution magnetic resonance imaging (HRMRI) for preoperative local staging in patients with rectal cancer who did not receive preoperative radiochemotherapy.

Methods: In this retrospective study, 30 patients with biopsy proved primary rectal cancer were evaluated by HRMRI. Two observers independently scored the tumour and lymph node stages, and circumferential resection margin (CRM) involvement. The sensitivity, specificity, the negative predictive value and the positive predictive value of HRMRI findings were calculated within the $95 \%$ confidence interval. The area under the curve was measured for each result. Agreement between two observers was assessed by means of the Kappa test.

Results: In T staging the accuracy rate of HRMRI was $47-67 \%$, overstaging was $10-21 \%$, and understaging was $13-43 \%$. In the prediction of extramural invasion with HRMRI, the sensitivity was $79-89 \%$, the specificity was $72-100 \%$, the PPV was $85-100 \%$, the NPV was $73-86 \%$, and the area under the curve was $0.81-0.89$. In the prediction of lymph node metastasis, the sensitivity was $58-58 \%$, the specificity was 50-55\%, the PPV was 43-46\%, and the NPV was 64-66\%. The area under the curve was 0.54-0.57. When the cut off value was selected as $1 \mathrm{~mm}$, the sensitivity of HRMRI was $38-42 \%$, the specificity was $73-82 \%$, the PPV was $33-42 \%$, and NPV was $79-81 \%$ in the prediction of the CRM involvement. The correlation between the two observers was moderate for tumour staging, substantial for lymph node staging and predicting of CRM involvement.

Conclusion: Preoperative HRMRI provides good predictive data for extramural invasion but poor prediction of lymph node status and CRM involvement.
\end{abstract}

Key words: Rectum, rectum cancer, magnetic resonance imaging, tumor staging

\section{Özet}

Amaç: Preoperatif radyokemoterapi uygulanmamış rektum kanseri hastalarında yüksek rezolüsyonlu manyetik rezonans görüntülemenin (YRMR) lokal evrelemedeki etkinliğini araştırmaktır.

Yöntemler: Bu retrospektif çalışmada biyopsi ile primer rektum kanseri tanısı almış 30 hastanın preoperatif YRMR'ı çift kör olarak olarak değerlendirildi. İki ayrı değerlendiricinin yaptığı T ve N evrelemesi ile tümörün mezorektal fasyaya olan uzaklığı histopatolojik evre ile karşılaştııldı. İki değerlendirici arasındaki uyum, Kappa testi kullanılarak araştıııldı. Ekstramural invazyonu belirlemede, lenf nodu metastazlarını ve çevresel rezeksiyon sınııını (ÇRS) saptamada MR'ın duyarlıık, özgüllük, pozitif ve negatif öngörü değerleri \%95 güven aralığında hesaplandı. ROC eğrisi altındaki alan hesaplandı.

Bulgular: YRMR'nin T evrelemesinde doğruluk oranı \%47-67, yüksek evreleme oranı \%10-21, düșük evreleme oranı ise \%13-43 idi. Ekstramural invazyonu belirlemede YRMR'nin duyarllığı \%79-89, özgüllüğü \%72-100, doğruluk oranı \%84-90, pozitif öngörü değeri \%85100, negatif öngörü değeri \%73-86, eğri altında kalan alan 0,81-0,89 idi. Lenf nodu metastazı varlığını belirlemede duyarlıık \%58, özgüllük \%50-55, pozitif öngörü değeri \%44-47, negatif öngörü değeri \%64-66, eğri altında kalan alan 0,54-0,57 olarak bulundu. Eşik değeri 1 mm olarak seçildiğinde ÇRS'yi belirlemede YRMR'ın duyarlıı̆ı \%38-42, özgüllüğü \%73-82, doğruluk oranı \%63-73, pozitif öngörü değeri \%3342, negatif öngörü değeri \%79-81 idi. İki gözlemci arasındaki uyum T evrelemede orta, N evrelemede ve ÇRS ölçümlerinde gerçek olarak saptandı.

Sonuç: Preoperatif YRMR T evrelemede iyi prediktif bilgi vermekle birlikte, N evrelemede ve ÇRS'yi değerlendirmede sorunlar bulunmaktadır.

Anahtar kelimeler: Rektum, rektum kanseri, manyetik rezonans görüntüleme, tümör evrelemesi

Address for Correspondence: Funda Obuz MD, Dokuz Eylül University, Department of Radiology, İzmir, Turkey

Phone: +90 2324122222 E-mail: fobuz@deu.edu.tr Received: 19.11.2012 Accepted: 13.04.2013 


\section{Introduction}

Rectal cancer, defined as a tumour with its lower edge within $15 \mathrm{~cm}$ from the anal verge, accounts for about a third of all colorectal malignancies. Management is particularly challenging technically for the surgeon and local recurrence within the pelvis is a common result of treatment failure. The introduction of the concept of total mesorectal excision (TME) has resulted in a decline in local recurrence rates (1). There is evidence that preoperative radiotherapy may further reduce the rate of local tumour recurrence $(2,3)$. The benefits of radiotherapy seem most marked in patients with T3, T4 or node positive disease. Involvement of the circumferential resection margin (CRM) by tumour is believed to be the main cause of local recurrence after rectal cancer surgery $(1,4,5)$. The clinical challenge is to identify preoperatively the cohort of rectal cancer patients who are at high risk of local tumour recurrence. Preoperative radiotherapy could then be applied selectively to this subgroup. Hence, accurate preoperative staging is of paramount importance. Recent publications have suggested that detailed rectal anatomy can be demonstrated using thin section magnetic resonance (MR) imaging with a pelvic phased-array coil $(5,6,7)$. This technique permits accurate T-stage determination and determination of the tumour involving surgical resection margins. The ability of thin section MR imaging in identifying the mesorectal fascia has been demonstrated, but there is conflicting evidence regarding the overall accuracy of MR imaging in staging rectal cancer $(7,8,9,10,11,12,13)$. The purpose of our study was to assess the overall diagnostic accuracy of HRMRI for preoperative $\mathrm{T}$ and $\mathrm{N}$ staging and prediction of the CRM involvement in patients with rectal cancer who had not received preoperative radiochemotherapy.

\section{Materials and Methods}

\section{Patients}

Institutional Review Board approval was obtained for this study. Between April 2003 and January 2008, 203 consecutive patients with biopsy-proved rectal cancer were staged preoperatively using HRMRI. Thirty of these patients (18 males and 12 females; mean age, 65.9 (range, 25-80) years) who had undergone surgical resection and had not been given preoperative radiochemotherapy were included in this retrospective study. Rectal tumours were defined as tumours within $15 \mathrm{~cm}$ of the anal margin.

\section{MR Imaging Techniques}

All patients underwent HRMRI with a $1.5 \mathrm{~T}$ system (Philips Gyroscan Intera Release 8, Eindhoven, Netherlands). A four-element pelvic phased-array surface coil was used. Patients were examined in the supine position after applying an antispasmodic agent (Buscopan). Patients did not undergo rectal air insufflations, nor did they receive bowel preparation or intravenous contrast. Sagittal fast spin-echo
T2-weighted (TR/TE:3500-4000/70-85, section thickness 3 $\mathrm{mm}$, intersection gap $0.8 \mathrm{~mm}$, matrix $256 \times 512$, number of signals acquired 6, field of view $22 \mathrm{~cm}$ ) images were obtained. These images were used to plan fast spin-echo T2-weighted para-axial images perpendicular to the long axis of the tumour. These images were obtained using an 18-cm field of view. The other parameters were the same as sagittal images. The last sequence was fast spin-echo T2weighted para-coronal images parallel to the long axis of the tumour (field of view $22 \mathrm{~cm}$ ). All images were reviewed using a high definition monitor and Easy-Vision software supplied by Philips Medical System.

\section{Evaluation of Images}

The patient's staging was done according to the TNM five classification. Briefly, T2 tumours involve the muscularis propria, T3 tumours extend to the perirectal fat and T4 tumours directly invade other organs or structures, and /or perforate visceral peritoneum. NO status refers to absence of nodal disease. Stage N1 denotes the presence of one to three malignant nodes and stage N2 denotes the presence of four or more malignant nodes. (please insert a reference)We used a size criterion of $5 \mathrm{~mm}$ maximum short axis nodal diameter for discriminating between benign and malignant nodes.(please insert a reference) For the prediction of the CRM, the observers assessed the HRMRI scans for the shortest distance from the outermost part of the tumour to the adjacent mesorectal fascia at the level of the maximum depth of penetration through the bowel wall. The distance was measured on the axial images with an Easy Vision Workstation (Philips Medical Systems). If a cancer was staged T1 or T2, the observer measured the shortest distance from the bowel wall at the level and site of the tumour to the adjacent mesorectal fascia. When an extramural tumour deposit or suspected lymph node was located nearer to the mesorectal fascia than to the primary tumour, this was used for measuring the closest distance to the fascia. If the distance between tumour or involved lymph node and mesorectal fascia was $\leq 1 \mathrm{~mm}$, CRM was defined as involved. When the distance was more than 1 $\mathrm{mm}, \mathrm{CRM}$ was defined as uninvolved. When the tumour invaded another organ (stage T4), the mesorectal resection plane was involved.

\section{Surgery}

All patients underwent standard mesorectal excision in the pre-sacral plane. This technique involved sharp dissection of the rectum and its surrounding fat within an intact mesorectal fascia. The inferior hypogastric nerves were preserved. Anteriorly, the specimen included intact Denonvillier's fascia and peritoneal reflection.

\section{Pathology}

The extent of local tumour staging was assessed according to the TNM system. The CRM involvement was calculated. 


\section{Statistical Analysis}

The results of HRMRI analyzed by the two observers were correlated with pathologic staging (pT and $\mathrm{pN}$ staging). Agreement between radiologic staging of the tumour, local lymph nodes, and CRM involvement with pathologic reporting and agreement between the two observers were assessed by means of the kappa statistics.

For extramural invasion, metastatic lymph node involvement and CRM involvement, the sensitivities, specificities, the negative predictive values and the positive predictive values of HRMRI were calculated within the 95\% confidence interval. The observer performances were examined by analysis of ROC curves. The area under the curve was used to indicate the overall performance of HRMRI.

Statistical analyses were performed with SPSS 15.0.

\section{Results}

Depending on the localization, rectal carcinoma was in the distal rectum in 12 patients, in the middle rectum in 13 patients, in the superior rectum in 5 patients.

According to histopathologic staging of the 30 patients, 7 (23.3\%) had pT1, 4 (13.3\%) had pT2, $12(40 \%)$ had pT3, and 7 (23.3\%) had pT4 tumour (Table 1). Eighteen patients (60\%) were classified as N0, nine patients (30\%) were classified as $\mathrm{N} 1$ and three patients (10\%) were classified as N2.

In T staging, the accuracy rate of HRMRI was $47-67 \%$, overstaging was $10-21 \%$, and understaging was $13-43 \%$ according to both observers. In the prediction of extramural invasion with HRMRI, the sensitivity was $79-89 \%$, the specificity was $72-100 \%$, the PPV was $85-100 \%$, and the NPV was $73-86 \%$. The area under the curve was $0.81-0.89$.

In predicting lymph node metastasis, the sensitivity was $58-58 \%$, the specificity was $50-55 \%$, the PPV was $43-46 \%$, and the NPV was $64-66 \%$. The area under the curve was 0.54-0.57.

When the cut off value was selected as $1 \mathrm{~mm}$, the sensitivity of HRMRI was $38-42 \%$, the specificity was $73-$ $82 \%$, the PPV was $33-42 \%$, and NPV was $79-81 \%$ in the prediction of the CRM involvement. The area under the curve was 0.63-0.65.

Statistically, there was good correlation between pathologic and radiologic evaluation of extramural invasion ( $k=0.73$ according to the first observer, $k=0.63$ according to the second observer). There was poor correlation between pathology and radiology in the prediction of lymph node metastases ( $k=0.07$ according to the first observer, $k=0.13$ according to the second observer). There was fair correlation between pathologic and radiologic reporting of CRM involvement ( $k=0.25$ according to the first observer, $k=0.20$ according to the second observer). However, the correlation between the two observers was moderate for tumour staging, substantial for lymph node staging and prediction of CRM involvement. Results are summarised in Table 2, 3, 4.

\section{Discussion}

Colorectal cancer is a major health problem and its' incidence is increasing (14). One-third of all colorectal cancers occur in the rectosigmoid or rectal region. Rectal

Table 1. Histopathologic stages of the patients

\begin{tabular}{ccc}
\hline Histopathologic stage & Number of patients & $(\%)$ \\
\hline T1 & 7 & 23.3 \\
T2 & 4 & 13.3 \\
T3 & 12 & 40.0 \\
T4 & 7 & 23.3
\end{tabular}

\section{Table 2. The efficacy of HRMR imaging in the prediction of extramural invasion}

\begin{tabular}{lccccc}
\hline MR & Sensitivity (\%) & Specificity (\%) & PPV (\%) & NPV (\%) & AUC (Az) \\
\hline Observer 1 & 79 & 100 & 100 & $(43-91)$ & 0.89 \\
Observer 2 & $(53-93)$ & $(67-100)$ & $(74-100)$ & 86 & 0.81 \\
& 89 & 72 & $(74-100)$ & $(44-91)$ \\
\hline
\end{tabular}

(PPV: Positive predictive value, NPV: Negative predictive value, AUC: Area under the curve, numbers in parentheses is $95 \%$ confidence interval)

Table 3. The efficacy of HRMR imaging in the prediction of CRM involvement

\begin{tabular}{|c|c|c|c|c|c|}
\hline MR & Sensitivity (\%) & Specificity (\%) & PPV (\%) & NPV (\%) & $A \cup C(A z)$ \\
\hline \multirow[t]{2}{*}{ Observer 1} & 38 & 82 & 42 & 79 & 0.65 \\
\hline & $(10-74)$ & $(60-94)$ & $(11-79)$ & $(57-92)$ & \\
\hline \multirow[t]{2}{*}{ Observer 2} & 42 & 73 & 33 & 81 & 0.63 \\
\hline & $(11-79)$ & $(51-88)$ & $(9-69)$ & $(57-93)$ & \\
\hline
\end{tabular}

(PPV: Positive predictive value, NPV: Negative predictive value, AUC: Area under the curve, numbers in parentheses is $95 \%$ confidence interval) 
Table 4. The efficacy of HRMR imaging in the prediction of lymph node metastases

\begin{tabular}{|c|c|c|c|c|c|}
\hline$M R$ & Sensitivity (\%) & Specificity (\%) & PPV (\%) & NPV (\%) & $\mathrm{AUC}(\mathrm{Az})$ \\
\hline \multirow[t]{2}{*}{ Observer 1} & 58 & 50 & 43 & 64 & 0.54 \\
\hline & $(28-83)$ & $(26-73)$ & $(20-69)$ & $(35-86)$ & \\
\hline \multirow[t]{2}{*}{ Observer 2} & 58 & 55 & 46 & 66 & 0.57 \\
\hline & $(28-83)$ & (31-77) & $(22-72)$ & $(38-87)$ & \\
\hline
\end{tabular}

(PPV: Positive predictive value, NPV: Negative predictive value, AUC: Area under the curve, numbers in parentheses is $95 \%$ confidence interval)

cancer carries a poor prognosis because of the risk both for metastases and for local recurrences. After curative resection, local recurrence rates of rectal cancer can vary from $3 \%$ up to $32 \%$ (15). Local recurrence is usually nonresectable and is associated with unpleasant symptoms that are difficult to palliate. Although postoperative radiotherapy allows selection of patients on the basis of histopathological risk factors, it seems to have little impact on survival (16). In contrast, preoperative (neoadjuvant) radiochemotherapy has been shown to reduce the rates of local recurrence and to improve survival $(2,3)$. The major weakness of this strategy is its toxicity (17). There is a need for accurate preoperative staging to allow patient selection for such treatment.

\section{T Staging}

Transrectal MRI using an endorectal coil can generate images with good spatial resolution due to its high signalto-noise ratio. This provides more accurate information about wall penetration than conventional MRI. However, as in the case of transrectal ultrasound, its use is limited by the necessity for specialised, dedicated equipment, poor patient acceptability and limited access to the tumour in patients with high or stenosing lesions. The assessment of the mesorectal fascia is also hampered by its limited field of view $(5,9,18,19,20)$.

With the introduction of new imaging sequences and thin section technique (HRMRI), Brown et al. was able to demonstrate 100\% accuracy and complete interobserver agreement in the staging of 25 primary rectal lesions (7). This initial high accuracy and reproducibility however was not confirmed. Blomqvist et al., using a 1.5 T scanner and pelvic phased-array coil, reported that the accuracy of predicting a T3 lesion was $78 \%$, with a sensitivity of $86 \%$ and specificity of $65 \%$ (9). Using a similar technique, BeetsTan et al. showed overall accuracy rates of $67-83 \%$ in the prediction of the tumour stage. There was also substantial interobserver variability in this study. Most of the staging failures occurred in differentiating T2 from early T3 lesions (8). According to Brown et al. only tumours with rounded or nodular advancing margin out with the muscularis propria should be regarded as T3 lesions (7). However, Beets-Tan et al. had difficulties in differentiating peritumoral inflammation or fibrosis from early tumour infiltration and concluded that tumours with fine strandings or spiculations in the adjacent perirectal fat should be classified as T3 lesions (8). Possible reasons for these differences may be due to the differing patterns of use of preoperative radiotherapy; all patients in the study of Brown et al. had received short course radiotherapy one week before resection (7). A recent meta-analysis including 21 studies performed with MRI using phase-array coil demonstrated $87 \%$ sensitivity, $75 \%$ specificity and 20.4 diagnostic odds ratio (DOR) for T staging (21).

In our study depending on the tumour localization, 12 patients had lower, 13 had middle and 5 had superior rectal cancer. Our overall T-staging accuracy was 47-67\%. In the prediction of extramural invasion with HRMRI, the sensitivity was $79-89 \%$, the specificity was $72-100 \%$, the PPV was $85-100 \%$, the NPV was $73-86 \%$, and the area under the curve was $0.81-0.89$. There was good correlation between pathologic and radiologic evaluation of extramural invasion. Two of the 30 patients were evaluated wrongly as T3 lesions. As mesorectum is thinner in lower rectum than superior, staging failures in that localization is a common problem. In our study, 8 patients having lower rectum cancer were staged wrongly: four of them were overstaged and the rest were understaged. The overstaged 4 tumours were predicted as T3 lesions because of inappropriate visualizing of the muscularis propria. The first observer understaged 5 patients as T3 that 4 of were invaded in visceral peritonium (Figure 1).

\section{N Staging}

The preoperative assessment of regional lymph node status forms part of the overall staging of any rectal tumour. Nodal status remains a critical prognostic factor in patients with rectal cancer. Accurate prediction of nodal status may thus influence preoperative treatment strategies. The application of a size criterion of $5 \mathrm{~mm}$ maximum short axis nodal diameter for discriminating between benign and malignant nodes has a moderate sensitivity and specificity for the detection of nodal metastases (5, $22,23)$. In a meta-analysis of imaging studies used for the staging of rectal cancer, it was found that there were no significant differences among endorectal sonography, CT, and MRI in nodal staging. The sensitivity and specificity of endorectal sonography, $\mathrm{CT}$, and MRI for detecting lymph node metastasis were $67 \%$ and $78 \%, 55 \%$ and $74 \%$, and $66 \%$ and $76 \%$ respectively (10). In a comparative study, 


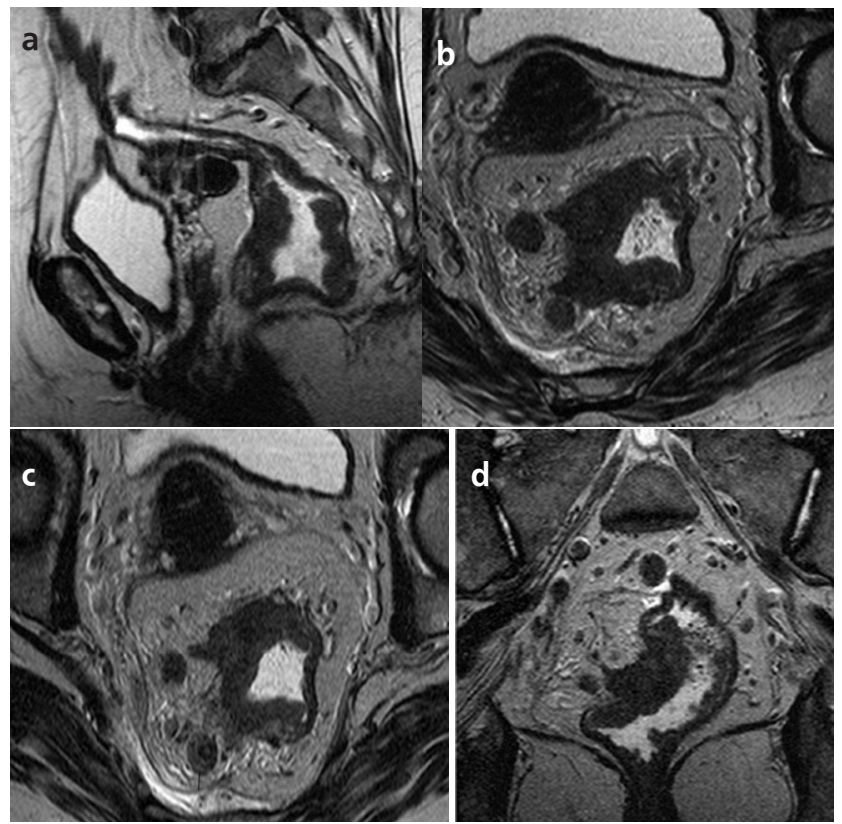

Figure 1. 54-year-old woman with pT4N1 rectal cancer. Two observers staged the tumor as T3N2 in the preoperative MR imaging. a- T2-weighted sagittal MR image shows the tumor.

b- T2-weighted para-axial MR image shows the tumor with nodular extramural invasion and perirectal lymph node metastasis. c- On T2-weighted para-axial MR image, the distance between involved lymph node and mesorectal fascia was more than $1 \mathrm{~mm}$ and CRM was defined as uninvolved. But histopathologically CRM was defined as involved.

d- T2-weighted para-coronal MR image shows the tumor and lymph nodes.

the accuracies of HRMRI and PET-CT were $83 \%$ and $70 \%$ respectively in the prediction of lymph node status of rectal cancer (24). A recent meta-analysis showed $77 \%$ sensitivity, $71 \%$ specificity and 8.3 diagnostic odds ratio (DOR) for $\mathrm{N}$ staging on MRI (21).

Imaging studies have shown a limited diagnostic accuracy using size criteria, but morphological criteria substantially improve this accuracy. Malignant nodes were found to have irregular outlines or to exhibit heterogeneous signal intensity on T2-weighted MRI $(23,25,26)$. If either of these criteria was present, a sensitivity of $85 \%$ and a specificity of $97 \%$ were achieved for detecting nodal metastases in nodes $\geq 3 \mathrm{~mm}$ (26).

There are some pitfalls in predicting LN status on MRI, leading to the false-positive results. First, as it has been discussed, the reactive $L N$ swelling makes it difficult to be differentiated from involved nodes. Second, continuous (or sometimes discontinuous) tumour deposits could mimic the involved LN, resulting in overestimation of LN positivity. To avoid this kind of overestimation, direct continuity with the main tumour should be carefully assessed on multiplanar images. Differentiation between involved nodes and discontinuous extranodal tumour deposits (satellites) without residual nodal tissue has not been solved yet on microscopy, much less on imaging. Third, the postradiation effect is lying in wait to make the interpretation of MR imaging difficult. Edema of the perirectal fat tissue by radiation and postradiation fibrosis around the LN may result in false-positive results of LN status $(23,27)$.

Preliminary experience using USPIO promises to improve this accuracy still further due to the ability to discriminate between malignant and non-malignant nodes based on the pattern of contrast uptake. Lahaye et al. reported that USPIO enhanced MR imaging had $93 \%$ sensitivity and $96 \%$ specificity in detecting lymph node metastases (28).

Our study using the size criteria for the detection of LN metastases had poor results (Figure 2). Among 30 patients, metastatic mesorectal lymph nodes (N1-2) were found in 12 patients. Predicting lymph node metastasis, the sensitivity was $58-58 \%$, the specificity was $50-55 \%$, the PPV was $43-46 \%$, the NPV was $64-66 \%$, and the area under the curve was $0.54-0.57$. Statistically, there was poor correlation between pathologic and HRMRI node staging.

In the present study, the assessment was performed retrospectively on a per-patient basis on the pathology report and this is the main limitation of this study. It is difficult to indicate which of the LN was truly positive in patients with nodal involvement. The main problem in our study was poor prediction of lymph node status because of the reactive lymph nodes.

\section{CRM Involvement}

One of the major advantages of HRMRI is the visualisation of the mesorectal fascia. The identification of this important surgical landmark is the key to deciding whether neoadjuvant chemoradiotherapy is advisable. Several series have demonstrated the potential of MRI in predicting the distance between the tumour and this fascial plane $(8,29,30)$.

Prediction of tumour-free CRM is important in the preoperative assessment of rectal cancer, and highresolution rectal MRI is regarded as a superior preoperative imaging modality for this purpose. CRM involvement is the single most powerful predictor of local recurrence in rectal cancer, and consequently, assessment of the CRM, or mesorectal fascia, has become important in the assessment of patients $(1,4,5)$. HRMRI has a sensitivity of $60-88 \%$ and a specificity of $73-100 \%$ for determining CRM status (11). A meta-analysis including nine studies and 529 patients reported that the sensitivity and specificity of MRI for detecting CRM involvement were 94\% and 85\% respectively (31). A recent meta-analysis revealed $77 \%$ sensitivity, 94\% specificity and 56.1 diagnostic odds ratio (DOR) for predicting CRM involvement on MRI (21).

Our study showed that MRI is able to predict those patients in whom the CRM is not involved, allowing them to proceed to surgery without the need for preoperative 


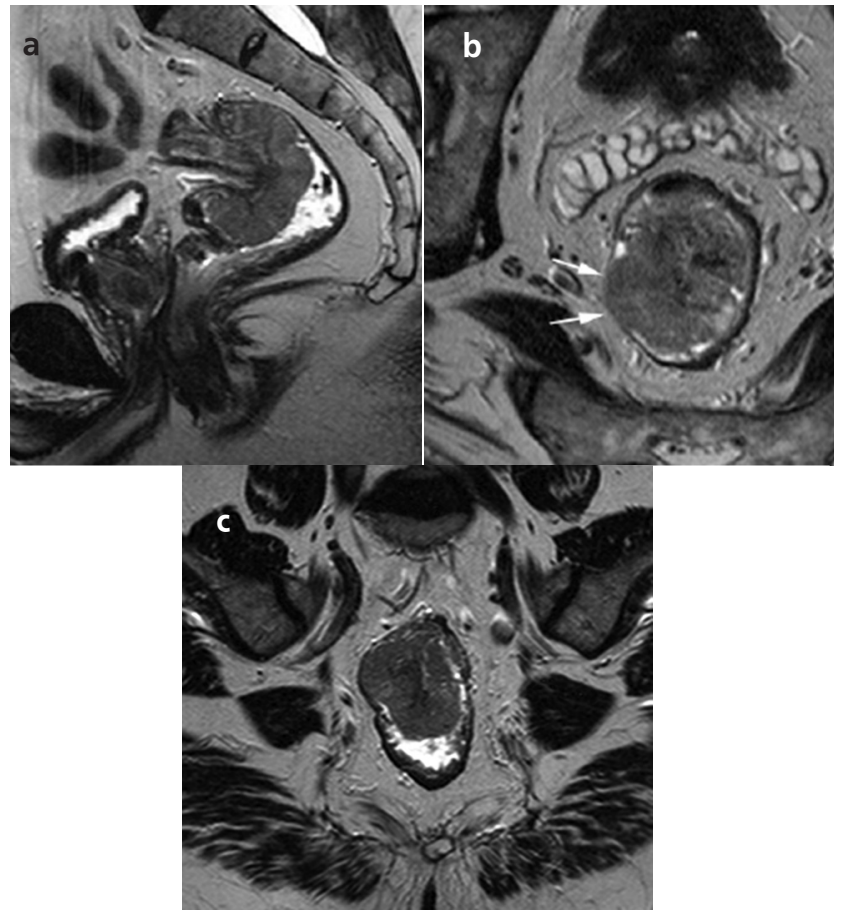

Figure 2. 68-year-old man with pT2N1 rectal cancer. Two observers staged the tumor as T2NO in the preoperative MR imaging. a- T2-weighted sagittal MR image shows the polipoid tumor. b- T2-weighted para-axial MR images show the tumor with invasion of muscle layer but not extending beyond it. It was confirmed at histopathology.

c- T2-weighted para-coronal MR image shows the tumor. Perirectal ovoid lymph node measured $7 \times 3.5 \mathrm{~mm}$ that has smooth borders and homogeneous signal intensity was evaluated as benign. But histopathology revealed lymph node metastasis.

radiotherapy. Predicting CRM involvement, the PPV was 33$42 \%$, the NPV was $79-81 \%$, and the area under the curve was $0.63-0.65$ (Figure 3). In 4 of $7(41 \%)$ patients with affected margin, this had not been predicted by magnetic resonance imaging before the surgery. In four patients predicted by the first observer, and six patients by the second observer, although the local extent of tumour had been correctly documented compared with pathology, the distance to the mesorectal fascia had been overestimated. As the perirectal fat tissue is thinner at lower rectum, three of these patients having tumour at that localisation were overstaged by both observers.

One of the important limitations of our study was the low number of patients. Moreover, since the study is a retrospective one, radiological-pathological correlation was conducted on the reports but not on macroscopic material, which was another important limitation. In the pathology reports, only the distance between the tumour and CRM was stated and the distance between the lymph node and the mesorectal facia we assessed in our patients was not stated in detail.

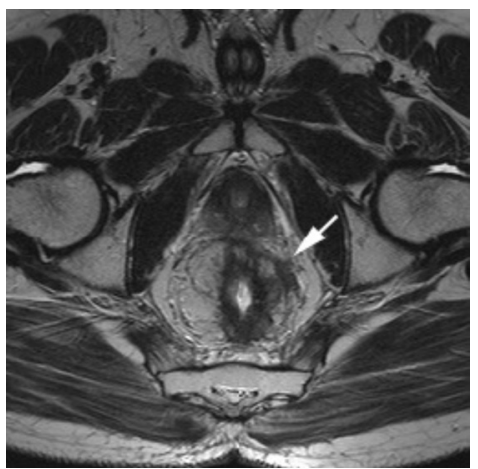

Figure 3. 29-year-old man with pT4N1 rectal cancer. First observer staged the tumor as T3N2, second observer staged as T4N2 in the preoperative MR imaging. Two observers accurately predicted CRM involvement. T2-weighted para-axial MR image shows the tumor with mesorectal fascia invasion at the left side.

\section{Conclusions}

As the conclusion, since the recent introduction of new treatment strategies for rectal cancer, there is a growing need for an accurate imaging tool to select patients preoperatively with different risks for recurrence so that treatment can be given according to the risks. Preoperative HRMRI does produce a reliable prediction of clear circumferential resection margins and provides valuable information in assessing whether patients can be proceeded to surgery without the need for preoperative radiotherapy. Our study shows that preoperative HRMRI provides good predictive data for extramural invasion but poor prediction of lymph node status because of the reactive lymph nodes and poor staging in CRM involvement.

\section{References}

1. Heald RJ, Ryall RD. Recurrence and survival after total mesorectal excision for rectal cancer. Lancet 1986;1:1479-1482.

2. Swedish Rectal Cancer Trial. Improved survival with preoperative radiotherapy in resectable rectal cancer. New Engl J Med 1997;336:890-987.

3. Kapiteijn E, Marijnen CA, Nagtegaal ID, Putter $H$, Steup WH, Wiggers T, Rutten HJ, Pahlman L, Glimelius B, van Krieken JH, Leer JW, van de Velde CJ. Dutch Colorectal Cancer Group. Preoperative radiotherapy combined with total mesorectal excision for resectable rectal cancer. N Engl J Med 2001;345:638-646.

4. Wibe A, Rendedal PR, Svensson E, Norstein J, Eide TJ, Myrvold HE, Søreide O. Prognostic significance of the circumferential resection margin following total mesorectal excision for rectal cancer. $\mathrm{Br} J$ Surg 2002:89:327-334.

5. Beets-Tan RG, Beets GL. Rectal cancer: review with emphasis on MR imaging. Radiology 2004;232:335-346.

6. Brown G, Daniels IR, Richardson C, Revell P, Peppercorn D, Bourne $\mathrm{M}$. Br J. Techniques and trouble-shooting in high spatial resolution thin slice MRI for rectal cancer. The British Journal of Radiology 2005:78:245-251.

7. Brown G, Richards CJ, Newcombe RG, Dallimore NS, Radcliffe AG, Carey DP, Bourne MW, Williams GT. Rectal carcinoma: thin-section MR imaging for staging in 28 patients. Radiology 1999;211:215222. 
8. Beets-Tan RG, Beets $G L$, Vliegen RF, Kessels AG, Van Boven $H$, De Bruine A, von Meyenfeldt MF, Baeten CG, van Engelshoven JM. Accuracy of magnetic resonance imaging in prediction of tumour free resection margin in rectal cancer surgery. Lancet 2001;357:497504.

9. Blomqvist L, Machado M, Rubio C, Gabrielsson N, Granqvist S, Goldman S, Holm T. Rectal tumour staging: MR imaging using pelvic phased-array and endorectal coils vs endoscopic ultrasonography. Eur Radiol 2000;10:653-660.

10. Bipat S, Glas AS, Slors FJ, Zwinderman AH, Bossuyt PM, Stoker J. Rectal cancer: local staging and assessment of lymph node involvement with endoluminal US, CT, and MRI-a meta-analysis. Radiology 2004;232:773-783.

11. Gowdra Halappa V, Corona Villalobos CP, Bonekamp S, Gearhart SL, Efron J, Herman J, Kamel IR. Rectal Imaging: Part I, High- resolution MRI of carcinoma of the rectum at 3 T. AJR 2012;199:35-42.

12. Taylor FGM, Swift RI, Blomqvist L, Brown G. A systematic approach to the interpretation of preoperative staging MRI for rectal cancer. AJR 2008;191;1827-1835.

13. MERCURY Study Group. Extramural depth of tumor invasion at thin-section MR in patients with rectal cancer: results of the MERCURYstudy. Radiology 2007;243:132-139.

14. Obias VJ, Reynolds HL. Multidisciplinary teams in the management of rectal cancer. Clinics In Colon And Rectal Surgery 2007;20:143147.

15. Sagar PM, Pemberton $\mathrm{JH}$. Surgical management of locally recurrent rectal cancer. Br J Surg 1996;83:293-304.

16. Minsky BD. Role of adjuvant therapy in adenocarcinoma of the rectum. Semin Surg Oncol 1999;17:189-198.

17. Birgisson $H$, Pahlman L, Gunnarsson $U$, Glimelius B. Adverse effects of preoperative radiation therapy for rectal cancer: Long term follow-up of the Swedish rectal cancer trial. J Clin Oncol 2005;23:8697-8705

18. Blomqvist L, Holm T, Rubio C, Hindmarsh T. Rectal tumoursMR imaging with endorectal and/or phased-array coils, and histopathological staging on giant sections: a comparative study. Acta Radiol 1997;38:437-444

19. Hunerbein M, Pegios W, Rau B, Vogl TJ, Felix R, Schlag PM. Prospective comparison of endorectal ultrasound, threedimensional endorectal ultrasound, and endorectal MRI in the preoperative evaluation of rectal tumors: preliminary results. Surg Endosc 2000;14:1005-1009.

20. Maldjian C, Smith R, Kilger A, Schnall M, Ginsberg G, Kochman $M$. Endorectal surface coil MR imaging as a staging technique for rectal carcinoma: a comparison study to rectal endosonography. Abdom Imaging 2000;25:75-80
21. Al-Sukhni E, Milot L, Fruitman M, Beyene J, Victor JC, Schmocker S, Brown G, McLeod R, Kennedy E. Diagnostic accuracy of MRI for assessment of $T$ category, lymph node metastases, and circumferential resection margin involvement in patiets with rectal cancer: a systematic review and meta-analysis. Ann Surg Oncol 2012;19:2212-2223.

22. Kim NK, Kim MJ, Park JK, Park SI, Min JS. Preoperative staging of rectal cancer with MRI: accuracy and clinical usefulness. Ann Surg Oncol 2000;7:732-737.

23. Koh DM, Brown G, Husband JE. Nodal staging in rectal cancer. Abdom Imaging 2006;31:652-659.

24. Kim DJ, Kim JH, Ryu YH, Jeon TJ, Yu JS, Chung JJ. Nodal staging of rectal cancer: High-resolution pelvic MRI and 18F-FDG-PET-CT. J Comput Assist Tomogr 2011;35:531-534.

25. Kim JH, Beets GL, Kim MJ, Kessels AG, Beets-Tan RG. High-resolution MR imaging for nodal staging in rectal cancer: are there any criteria in addition to the size? Eur J Radiol 2004;52:78-83.

26. Brown G, Richards CJ, Bourne MW, Newcombe RG, Radcliffe AG, Dallimore NS, Williams GT. Morphologic predictors of lymph node status in rectal cancer with use of high-spatial-resolution MR imaging with histopathologic comparison. Radiology 2003;227:371-377.

27. Ueno $H$, Mochizuki $H$, Hashiguchi $Y$, Ishiguro $M$, Miyoshi $M$, Kajiwara $Y$, Sato T, Shimazaki H, Hase K. Extramural cancer deposits without nodal structure in colorectal cancer. Am J Clin Pathol 2007;127:287-294.

28. Lahaye J, Beets-Tan RG. USPIO-enhanced MR imaging for nodal staging in patients with primary rectal cancer: predictive criteria: Radiology 2008;246:804:811.

29. Blomqvist L, Rubio C, Holm T, Machado M, Hindmarsh T. Rectal adenocarcinoma: assessment of tumor involvement of the lateral resection margin by MRI of resected specimen. $\mathrm{Br} J$ Radiol 1999;72:18-23.

30. Brown G, Radcliffe AG, Newcombe RG, Dallimore NS, Bourne MW, Williams GT. Preoperative assessment of prognostic factors in rectal cancer using high resolution magnetic resonance imaging. $\mathrm{Br} J$ Surg 2003;90:355-364.

31. Purkayastha S, Tekkis PP, Athanasiou T, Tilney HS, Darzi AW, Heriot AG. Diagnostic precision of magnetic resonance imaging for preoperative prediction of the circumferential margin involvement in patients with rectal cancer. Colorectal Dis 2007;9:402-411. 